\title{
EVIDENCE FOR LONG-TERM UPLIFT ON THE CANARY ISLANDS FROM EMERGENT MIO- PLIOCENE LITTORAL DEPOSITS
}

\author{
Meco, J. ${ }^{a}$, Scaillet, S. $^{b}$, Guillou, H. $^{b}$, Lomoschitz, A. $^{c}$, Carlos Carracedo, J. $^{d}$, Ballester, J. ${ }^{a}$, \\ Betancort, J.-F. ${ }^{a}$, Cilleros, A. ${ }^{\mathrm{c}}$
}

\begin{abstract}
a Paleontología, Departamento de Biología, ULPGC, 35017 Las Palmas de Gran Canaria, Spain
b Laboratoire des Sciences du Climat et de l'Environnement, LSCE, IPSL, 91198 Gif sur Yvette, France

c Departamento de Ingeniería Civil, ULPGC, 35017 Las Palmas de Gran Canaria, Spain

d Estación Volcanológica de Canarias, Instituto de Productos Naturales y Agrobiología, IPNA-CSIC, 38206 La Laguna, Tenerife, Spain
\end{abstract}

\begin{abstract}
Several islands in the Canarian archipelago show marine deposits with identical fossil faunas, which are generally assigned to different glacioeustatic marine episodes: mainly Pleistocene episodes in Lanzarote and Fuerteventura, and Mio-Pliocene ones in Gran Canaria. Three fossil species (Saccostrea chili, Nerita emiliana and Strombus coronatus) characterize all the marine deposits from southern Lanzarote, to the west and south of Fuerteventura and northeast of Gran Canaria. Three other species (Ancilla glandiformis, Rothpletzia rudista and Siderastraea miocenica) confirm the chronostratigraphic attribution of these deposits. Other more occasional fossils (as Chlamys latissima, Isognomon soldanii and Clypeaster aegyptiacus) fit an upper Miocene and lower Pliocene age. This agrees with new K/Ar ages obtained from pillow lavas emplaced into the marine deposits (ca. 4.1 Ma in Gran Canaria, ca. 4.8 Ma in Fuerteventura) and from underlying (ca. 9.3 Ma in Gran Canaria) or overlying (ca. 9.8 Ma in Lanzarote) lava flows. The marine deposits are eroded but large continuous segments are preserved sloping gently towards the coast. Variations in the highest and the lowest elevations of the deposits apsl (above present sea level) indicate post-depositional uplift movements. Glacioeustatic causes are unlikely to be responsible for these variations on the basis of the coastal location of the deposits and their equatorial fauna characteristic of Mio-Pliocene corals. Differential uplift of the deposits across the archipelago is argued to result from the progressive seaward tilting of the islands along the insular volcanic trail marking the westward migration of hot spot head since $20 \mathrm{Ma}$. Successive westward accretion of younger volcanic edifices resulted in increasing lithostatic load of the crust with progressive (diachronous) tilting of the older edifices and their palaeo-shorelines marked by past coastal deposits
\end{abstract}

